Article

\title{
Res aut res publica: The Evidence from Italian Renaissance Manuscripts and Their Owners
}

John M. McManamon, S. J.

History Department, Loyola University, Chicago, IL 60660, USA; E-Mail: jmcmana@luc.edu

Received: 31 March 2012; in revised form: 10 April 2012 / Accepted: 11 April 2012 /

Published: 11 April 2012

\begin{abstract}
This paper examines a key tension in Renaissance culture as reflected in the origin and provenance of manuscript books. Were Renaissance manuscripts the private property of individual owners or the common wealth of a lettered public? Even an officially public library could not escape that tension, whether through abuse of borrowing privileges or plundering of vulnerable holdings. Market forces encouraged theft, while impoverished scholars used their knowledge to supplement meager incomes. Alternatively, a sense of common wealth is reflected in an ex-libris indicating that a codex belonged to an individual "and his friends." Book collecting, finally, becomes a helpful clue in discerning to what a scholar is committed. Some Renaissance clergymen used culture as a way to promote their ecclesiastical careers, while others collected and shared manuscripts as a way to promote tolerance.
\end{abstract}

Keywords: renaissance; manuscripts; humanism; libraries; private property; common wealth

"Some <scholars> ... may even decide to read <the Iter Italicum>, just as I have enjoyed reading catalogues and inventories of manuscripts." 1

Paul Oskar Kristeller

Over a period of years in the recent past, I did read Kristeller's Iter Italicum. I found the experience exciting in a way that Carlo Ginzburg might appreciate: the historian as detective who unearths clues and follows where they lead ([2], pp. 96-125). Along the way, one encounters a tension related to Renaissance manuscripts: should one treat them as private property (res) or a common wealth

\footnotetext{
[1], 1, p. xxiv. I am grateful to the Center for Medieval and Renaissance Studies at UCLA and Loyola University

Chicago for generously supporting my research.
} 
(res publica)? Take the history of Cardinal Bessarion's books, bequeathed to the Venetian Republic for public use. From the start, the Venetian government set conditions for the loan of those books: that one be a Venetian resident, provide a valuable item as security for the loan and return the book within eight days. Despite such stringent conditions, there were soon problems. In 1494, the government decreed a fine of 500 ducats for recalcitrant borrowers. In the early sixteenth century, the Procurators of San Marco, custodians of the library, added a new condition: the loan would occur only when threequarters of their number approved. By 1506, the Procurators were ordered to stop all lending, get back in one week's time all books that were out or apply the 1494 penalty of 500 ducats. Nonetheless, lending continued, and matters did not improve.

When Andrea Navagero (1483-1529) served as librarian from 1516 to 1524, he actually brandished an apostolic Breve threatening excommunication for those who did not promptly return loaned books. The sanction had a precedent in the 1462 bull that Pius II issued to protect the new library that the Franciscan Giacomo della Marca (1393-1476) established in Monteprandone ([3], p. xxviii). Navagero's recourse to papal intervention means that he too had problems in getting borrowers to return books. And Navagero may have brought problems on himself. A letter that the Cretan scholar, Markos Mousouros (ca. 1470-1517), sent to Navagero on 8 May 1517 reveals questionable choices by borrowers and the librarian. For at least the second time, Mousouros emphasized to Navagero that he had evidence proving that individuals were stealing books from the library and selling them for personal gain. For example, the nephew of Venice's recently deceased Grand Chancellor, Francesco Fasiol (d. 1517), had purloined a copy of Apsyrtus's treatise on medicinal remedies for horses and then sold it to the bookseller Francesco Pozzi. While browsing in Pozzi's store, nestled among the apothecary shops selling spices in Venice (la spezzeria), Mousouros spotted the book, bought it, took it home and there recognized the clues that indicated its true provenance. The margins of the book still had Greek notes in Bessarion's hand, and the leaf where Bessarion often wrote a table of contents had been cut out. When Mousouros confronted Pozzi with the evidence, he confessed that he had bought the book from Fasiol's nephew. Mousouros next confronted Chancellor Fasiol, who was indignant and began surreptitiously to run down Mousouros's good name.

Books stolen from the Marciana not only found their way to Venice's booksellers but to artisans as well. The local barber near the church of Sant'Apollinare returned to Mousouros a copy of Bessarion's own In calumniatorem Platonis, stolen once again by Fasiol's nephew, who rightly assumed that he could sell the manuscript to the barber. Obviously, a barber would want a copy of Bessarion's defense of Plato in order to assist his son's study of Greek at Mousouros's school. Amid the darkness of the avarice of the human spirit shines the light of a barber's son, Domenego, seeking to become proficient in Greek. Because Mousouros did not have time to attend to the recovered books, he ordered that they be put with others he had left for safe keeping with his student, Carlo Cappello (1492-1546). Without telling Mousouros, some of his disciples (egline) put the books in cloth containers and sent them with Mousouros's other baggage to Rome. Mousouros assured Navagero that he still had the books and that they were "at your disposition" (al commando vostro). A diffident Navagero added a note to his copy of the letter, indicating that Alberto Pio da Carpi (1475-1531), another former student and lifelong friend of Mousouros, had come into possession of those books. Navagero seems to tip us off that Mousouros was currying favor with a patron or making his own profit on Marciana books. 
Other evidence indicates that Mousouros and Navagero respected the Marciana as a public institution. While Mousouros conducted negotiations in Rome to obtain for the Marciana the library of the Venetian cardinal, Domenico Grimani (1461-1523), Navagero worked to keep its books available to the scholarly public even in the absence of a permanent facility for their storage. In this exchange, however, both seem engaged in that perennial sport of covering for their actions. Mousouros was responding to an inquiry of Navagero about missing books, his explanation for the way the books reached Rome seems flimsy and he works to deflect blame by incriminating Navagero. Navagero never seemed properly concerned about Mousouros's repeated warnings that Fasiol and his nephew had abused borrowing privileges, and Navagero did nothing during Fasiol's lifetime to end the abuse. The librarian seemed cowed by powerful politicians. When notified of the theft of Bessarion's defense of Plato, Navagero told Mousouros not to worry about that particular book because the library had "an infinite number of copies." Though a bit short of infinite, the 1474 inventory of Bessarion's library listed four Greek copies and seven Latin translations of the entire work or portions thereof. ${ }^{2}$

What ultimately happened to the two stolen books? The trail has led us to the library of Alberto Pio da Carpi and from there might logically lead to the Biblioteca Estense in Modena. But Lotte Labowsky has argued that the copy of Apsyrtus cannot be found there or anywhere else, since the only copy of Bessarion's In calumniatorem Platonis presently in Modena and having Alberto Pio's library for its provenance (Est. gr. 125) is missing the marginalia of Bessarion that Mousouros described. Labowsky is therefore inclined to identify the copy briefly in the barber's possession with a codex now in the Vatican Library (Vat. gr. 1435) because the Vatican codex does have additions and corrections in Bessarion's hand. I would observe that the precise wording of Mousouros is not clear on the extent of Bessarion's notations: "having recognized some Greek letters of Bessarion in the margin" (havendo io recognosciuto certe lettere grece de Bessarione in margine). ${ }^{3}$

Alas, the following centuries likewise manifest cases of insiders, who exploited their position to pilfer manuscripts or portions thereof, especially as their market value increased. From a Jesuit perspective, Cardinal Zelada (1717-1801) brought dishonor on his given name, Francesco Saverio, by supporting the suppression of the Society of Jesus and then plundering the Jesuits' Roman residences for books and other valuable objects. ${ }^{4}$ In the nineteenth century, two Greeks climbed to the monastery of Vatopedi on Mount Athos, recognized the importance of a codex there that conserved rare texts of early Greek geographers and cut out some folios from the codex. Aubrey Diller identified the culprits: the first was Minoides Mynas, who visited Vatopedi in 1841 under commission of the Bibliothèque Nationale in Paris and left among his private papers seven leaves from Vatopedi 655 that the Bibliothèque Nationale acquired (Suppl. gr. 443A); the second was the "notorious Constantine Simonides," who gained entrée to Athos through an uncle who was an abbot there and sold the leaves that he stole from Vatopedi to the British Museum (Add. 19391). In a rather understated way, Aubrey

2 [4], 6, pp. 306-10; [5], pp. 318-19, 367-70; [6], pp. 63-64, 76-80, 115, 139-42, 486, 490; [7], pp. 100-2; and [8], pp. 329-30. All citations from Mousouros's letter are from [6], pp. 139-41.

3 [6], p. 79. See also [9], pp. 1-24 (Biblioteca Estense), p. 49 (a copy of Apsyrtus, dated s. XV-XVI, in Roma, Biblioteca dell'Accademia dei Lincei, cod. Nic. Ross. 358 [43.D.82]).

4 [10], pp. 118-20; [11], pp. 64-65, 67-89; and [12], pp. 184, 209, 219-20 n. 23. 
Diller describes Vatopedi cod. 655 as "somewhat dismembered." Mynas and Simonides had such a fascination with old Greek manuscripts that they would forge the ones they could not steal.

In that same century, Guglielmo Libri (1803-69) deservedly earned the title of "master manuscript thief," exploiting the trust of the Italian and French governments to steal their codices and sell them to the earl of Ashburnham. In another classic understatement, Libri wrote his mother in 1835 and informed her that "the more I age and work, the more I enjoy old books." ${ }^{\circ}$ From his more cautious beginnings in Florence, Libri gradually utilized his eye for valuable antiques and his talent for speculating on the book market to quicken his collecting. He eventually convinced the French government to catalog all manuscripts in France's provincial libraries, and he began visiting those libraries as a director of the initiative. Libri stole manuscripts from libraries in at least nine different cities, including Autun, for which he introduced the seminary library in the first volume of the Catalogue générale. When Libri offered manuscripts for sale to the British Museum, the Museum's librarians, while examining his collection in Paris, were tipped off to Libri's shady character, penchant to speculate and rumored theft of codices. Even after receiving that information, they still urged the British government to approve funds for the purchase. But the government did not feel that it could afford Libri's asking price. The true hero of the Libri saga, Leopold Delisle (1826-1910), concluded: "Enlightened men of all nations should agree to ostracize library pirates, who clandestinely carry abroad the fruits of their rapine, and <they> should combine to prevent any traffic in such articles" ([19], p. 285).

There is, at times, a curious disjunction between the quality of manuscript books commissioned by the richest patrons and the quality of the written texts conserved in those books. If the d'Este family did commission a luxury codex now in the Marciana (Marc. lat. XI.101), they received a book richly decorated with white-vine bordering and their own coat of arms and poorly written by a scribe whom Pietro Zorzanello (1883-1951) characterized as a "uomo proprio sfigurati," which one might roughly render, "a man truly to be numbered among the morons." Onto the folios of that beautiful container of quality parchment the scribe wrote a text filled with errors in rather crude letters (literis crassioribus). Zorzanello perhaps chose his words carefully: humanists of the Renaissance coined a diminutive form of crassior, "crassiusculus," for someone obtuse or mediocre ([21], 2, pp. 3 and 7; [22], p. 138). The same dynamic of poor copying probably took a few years off the life of Ciriaco d'Ancona (13911452). Ciriaco paid a scribe, Domenico di Cassio da Narni, to make two luxury copies of his letter on the battle of Ponza as gifts for wealthy patrons. At the last minute, due to Domenico's sloppy work, Ciriaco himself had to correct the texts before giving them to his supporters. Perhaps Ciriaco gambled that someone like Cardinal Giordano Orsini ( $c$. 1360-1438) would be happy to put the luxury codex on display in his home and never read it closely enough to notice those awkward, fifteenth-century equivalents of the "white out." Because Ciriaco found himself pressed for time, he failed to catch

[13], pp. 228-29; [14], pp. 177-79; [15], pp. 10-14; and [16], pp. 40-41, with quotation.

6 [17], pp. 53 n. 2 (letter of 26 May 1835): “... Quanto più invecchio e lavoro mi piacciono i libri antichi e sono contento solo quando perduto nei secoli passati oblio il presente e non preveggo l'avvenire." In addition to [17], pp. 59-106, see also [18], pp. 5-21; [19], pp. 279-90; and [20], pp. 161-79, 202-31, 320-31. 
several errors and could not, therefore, assure a text whose accuracy would reflect his esteem for his patrons. ${ }^{7}$

Even a zibaldone (family hodgepodge book), at the opposite end of the spectrum from the luxury parchment codex, might still be plundered as an object of perceived value. During the sack of Volterra in 1472, a local humanist notary, Biagio Lisci (ca. 1423-after 10 Dec. 1517), had his family journal taken as booty by a soldier named Lisandrino. When the rapacious Lisandrino eventually realized that he had not looted an illuminated Dante, he sold the Lisci zibaldone for four soldi to the grammarian Luca di Antonio Bernardi da San Gimignano (d. after 1 June 1499). Luca was a personal friend of Lisci but at first assuaged any pangs of conscience for the purchase by apparently concluding that, in this instance, two wrongs did make a right. At one time, Lisci had borrowed Luca's copy of the Liber de temporibus written by the humanist Matteo Palmieri (1406-75), but Lisci had never returned the book and apparently had lost it. There is a clue, however, that the grammarian Luca later experienced a moment of authentic remorse: the Lisci zibaldone is now part of the manuscript collection of the Biblioteca Comunale Guarnacciana in Volterra (cod. 5031). Perhaps Luca gave the journal back to its owner, a lifetime resident of Volterra, or perhaps he traded the journal for another book ([23], pp. 24041; [24], pp. 25-28).

Down to our own times, scholars have speculated on the value of manuscripts first located during their research, utilizing legitimate and black markets. Ludwig Bertalot (1884-1960) had such an unstable income that he occasionally had to use his keen knowledge of manuscripts to support himself. In 1936, Bertalot recruited his American friend, Dean Lockwood (1883-1965), to serve as a gobetween with Harvard University, whom Bertalot hoped would buy manuscripts he then owned. When Harvard did not do so, Lockwood himself bought one codex in 1946, sold it to William H. Allen (1918-97) the following year, and Allen sold it to the University of Pennsylvania Library. ${ }^{8}$ Bertalot's behavior in the case of the codex Bolleanus seems less above board. After Remigio Sabbadini introduced Bertalot to Luigi Cesare Bollea (1877-1933), a Torinese historian, Bertalot recognized the value of a Renaissance miscellany that Bollea owned, and, in 1929, Bertalot purchased it. When forced by circumstances to sell the codex, Bertalot split it into two parts to maximize his profit, selling one piece to the national library in Berlin and another to the University Library in Frankfurt. However, until his death in 1960, Bertalot never revealed the division. In 1964, Kristeller and Giuseppe Billanovich identified the portion in Berlin and realized what Bertalot had done, which Billanovich characterized as a "regrettable, commercial decision" (con infelice, commerciale idea). Ursula JaitnerHahner had to follow a clue, a note on one of the thousands of index cards that comprised Bertalot's incipit catalogue, in order to identify the second piece of the manuscript ("Codex Frankfurt [olim

7 Roma, Biblioteca dell'Accademia dei Lincei, cod. Nic. Rossi 214 (35.E.27) (copied by Domenico di Cassio da Narni with autograph additions and corrections); and London, British Library, cod. Harley 4088 (copied by Domenico di Cassio da Narni with autograph additions). See [23], pp. 236-40; and [24], pp. 16-19.

8 Philadelphia, Univ. of Pennsylvania Library, cod. Lat. 7, with a note on fol. 105 that the Milanese humanist Lancino Curti (ca. 1460-1512) owned the codex in 1484. On the codex, see [1], 5, p. 372a-b; [25], pp. 247-52; [26], p. 83; [27], pp. 107-8; [28], 1, p. 253; and [29], 1, p. 154 (no. 2112). With the patronage of Ludovico Sforza (il Moro), the Lombard humanist Curti claimed to have written over 60,000 works. See [30], 31, pp. 487-88; and [31], pp. 10-11, 137-38, 190-203. 
Bollea], fol. 124v"). To assure maximum value for both halves, Bertalot cut out the leaf with the fifteenth-century possessors' notes, cut the leaf in two and pasted one possessor's note into each half. ${ }^{9}$

There seems no more eloquent image of the privatization of manuscripts books than the coffin-like boxes in which the self-described Vellomaniac, Thomas Phillipps (1792-1872), kept his more than 60,000 codices ([32], pp. 119-30; [33], pp. 91-94). As his personal property, the manuscripts were certainly dead to the world. By contrast, collective instincts are apparent in the ex libris of Renaissance intellectuals like Bartolomeo Fonzio (Della Fonte, 1446-1513), Angelo Poliziano (1455-94) and Francesco Pandolfini (1470-1520) in Florence, Giovanni Melzi (d. after 1482) in Milan and the Hellenophile Arcangelo in Rome. From the start, they labeled their books the property of themselves and their friends. ${ }^{10}$ The Venetian humanist Leonardo Giustiniani (ca. 1386-1446) was among the first to employ such an ex libris, crafted in, admittedly, pedantic Greek. ${ }^{11}$ Giustiniani likely knew the proverb that Plato, Aristotle and Cicero, among others, cited and that, in 1508, Erasmus awarded the honor of first place among his Adages: "all possessions are common to friends." ${ }^{12}$ Erasmus appreciated that adages constituted the ideal medium for his cherished message of a common intellectual patrimony, both classical and Christian. The adage is a literary form that, by nature, can never be private property.

Because Kristeller saw the Iter Italicum as a consciously collective enterprise, he dedicated the book to the librarians of Italy and the rest of the world. His characterization of the volumes as a "cooperative enterprise" was not false modesty. Kristeller did quote a remark that his friend Robert Branner made, to the effect that Kristeller's research team consisted mainly of his right and left arms

9 [27], pp. 99-111. Bertalot drafted but never sent a letter to Helmut Boese in Berlin, in which he revealed the location of the second piece. At about the same time that Jaitner-Hahner found Bertalot's notes, she received an inquiry from the University librarian in Frankfurt about incipits in cod. Lat. octavo 136. Prior to the publication of the Iter, vol. 3, Jaitner-Hahner informed Kristeller of her discovery so that he could include the information there.

10 In general, see [34], pp. 87-99. For Fonzio's formula, “Bartholomaei Fontii et amicorum,” see Caroti and Zamponi, 30. Caroti and Zamponi note that Poliziano and Fonzio's heir, Francesco Pandolfini, used a similar formula. Milano, Biblioteca Ambrosiana, cod. Sussidio H 52, belonged to Melzi ("Iste liber est mei Iohannis Meltii et amicorum"). Ambrosiana Sussidio H 52 is a composite codex dating from the mid-fifteenth century, has at least two hands, later entered the library of Count Donato Silva (1690-1779) and was purchased by the Ambrosiana from the bookseller Vergani. Melzi was a doctor of law and wealthy Sforza courtier, who wrote on ethics and Christian morality. We may know the name of one of Melzi's friends, Giovanni dei Pescatori, who left a borrower's note in Melzi's humanist miscellany. Apparently, Pescatori had more than one friend who owned manuscripts since other codices bear that same borrower's note written in vernacular dialect. See [1], 1, 347b-48a; [36], pp. 4-5; and [37], pp. 229-31, 234, $245-52$. Città del Vaticano, Biblioteca Apostolica Vaticana, cod. Vat. lat. 2936, has a bilingual possessor's note on fol. 1,

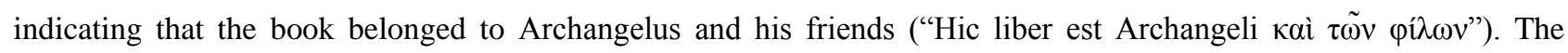
Vatican codex was written by two hands in the first half of the fifteenth century. See [1], 2, p. 357b; [29], 1, p. 202 (no. 2783); and [38], 2, pp. 315-16. It has form letters and orations of Antonius de Pizzinis Padovenis and a speech of Antonio Carabello (d. after 1436), who taught rhetoric at the University of Padua from 1434-36. On Carabello, see [39], pp. 470-74; and [40], 19, pp. 300-1.

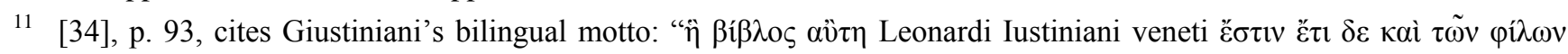

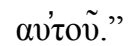

12 [34], pp. 93-94; and [41], pp. 4-5, 25-32, 67-68, 76-77, 81-108, 122-30, 138-41, 144-45, 148-52, 164, 168. For Adagiorum chiliades 1.1.1, see [42], pp. 84-86; English translation, [43], pp. 29-30. 
([1], 1, p. xxv; 3, pp. xviii-xix). Though Kristeller granted that the cataloging demanded persistence on his own part, he wanted the volumes to foster a shift from the individual adventure of scholarly research to collaboration on a broader scale. He therefore exhaustively acknowledged the assistance he received from scholars and institutions and granting agencies and, of course, librarians. Kristeller's emphasis on cooperation explains his dismay for a lack of solidarity among a minority of persons with whom he dealt. In the preface to volume 6, Kristeller revealed that "there were a few librarians who failed to cooperate, and I prefer not to mention them" ([1], 1, p. xxii). In addition, some private individuals who owned manuscripts permitted Kristeller to see them but would not allow him to reveal their location. In a choice that would please More and Erasmus, Kristeller put those manuscripts in Utopia.

Scholars of any era might readily give the award for "Exemplary Manuscript Collector" to Christopher Columbus's illegitimate son, Hernando Colón (1488-1539). Generally, when Colón bought a book-and he bought many-he recorded the date and place of purchase, the costs to him in the local currency and the date(s) on which he consulted the book thereafter [44]. The award for "Avid Manuscript Collector" should go, perhaps, to the Venetian Emmanuele Antonio Cicogna (1789-1868), who saved as many as 5,000 manuscripts from ruin. While hunting for the surviving portions of the library of the librettist Lorenzo Antonio da Ponte (1749-1838), Cicogna tracked down an autograph manuscript of Camillo Contarini (1644-1722) that he purchased from a cheese and butter vendor and a thick bundle of Arsenal papers from a delicatessen owner. It was not that there was a sudden burst of interest among grocers in Venice for early modern texts. Rather, the enterprising shopkeepers had discovered that old parchment leaves comprised a sturdy wrapping for food items. In fact, stacks of parchment sold for 6 soldi a pound. ${ }^{13}$ Imagine your due etti of prosciutto from San Daniele wrapped in a public letter of Leonardo Bruni.

Perhaps the best clue for contextualizing a Renaissance manuscript comes by pinning down its original owner. Though luxury illuminated codices make for successful exhibits, the majority of Renaissance codices are the working miscellanies of students of letters. When we follow the books of the students of Giovanni Lamola ( $c a$. 1405-49), a product himself of an excellent rhetorical education, we appreciate better that foreigners studying in Italy and books copied for them diffused humanism to other parts of Europe, especially the Rhine and Danube regions of the German Empire. Lamola had several humanist mentors, including Gasparino Barzizza, Vittorino da Feltre, Francesco Filelfo and Guarino. His life unwound in pendular fashion: he moved away from his hometown of Bologna to pursue pedagogical opportunities elsewhere only to move back after a time and resume his lecturing at the Studium. Late in 1447 and early in 1448, while Lamola was at Bologna and not long before he died, he taught the humanities to a small but influential group of German students, who then transmitted humanist culture to their native cities.

Johann Roth (1426-1506) fondly remembered Lamola as praeceptor meus after studying at Bologna in the 1440s, and the future prince-bishop first developed his lifelong interest in the humanities at Lamola's lectures ([46], pp. 351-53, 363; [47], pp. 403-405; [48], pp. 415-18). Hans Pirckheimer (ca. 1415-92) studied with Lamola, attributed his love for humanism to Lamola and

13 [7], pp. 327, 343. For the Da Ponte codices formerly owned by Leopold von Ranke and now at Syracuse University, see [45], pp. xi-xiii, 1-109 (codices 2, 3, 7, 15, 20, 47, 50, 63, 65, 70, 72, 73, 76, 81, 83, 104). 
began assembling at Bologna under Lamola's tutelage the massive compilation of texts in British Library codex Arundel 70. ${ }^{14}$ Iohannes Heller (ca. 1414-1475/8) met Lamola in Bologna and put together his own compendia of epistolary, poetic and rhetorical models, now München Universitätsbibliothek Quarto 768 (terminus ante quem of 1452 and likely finished in Italy in 1450) and München Staatsbibliothek Clm 6721 (modeled on the former). ${ }^{15}$ Hermann Schedel (1410-85) made one of Heller's compendia (Universitätsbibliothek Quarto 768) the nucleus of his own, now München Staatsbibliothek Clm 504, and Schedel then added in his hand the writings of Lamola and other authors active at Bologna at mid-century (Niccolò Perotti, Nicolò Volpe, Battista da San Pietro). Among the texts added, Schedel chose to include Lamola's panegyric for Jerome delivered in $1442 .{ }^{16}$ Humanist miscellanies resist rigorous taxonomy. Some of the texts copied into them perforce reflect serendipity, put there to demonstrate the acquired skills of the redactor himself or reflect that redactor's peculiar interests. However, a core of the works consistently included in multiple codices may well represent a sort of evolving textbook of rhetorical pedagogy that traces its roots to the teaching of Barzizza and Guarino and early included speeches of Leonardo Giustiniani, Leonardo Bruni and Poggio Bracciolini.

For example, after studying in Italy for fourteen years, Albrecht von Eyb (1420-75) put together a compendium of model texts that quickly found its way into print. By 1459, von Eyb had completed a first redaction of his Margarita poetica, whose title has likely misled some scholars. He originally went to Italy to study law under Catone Sacco (1394/7-1463) at the University of Pavia. When Sacco moved from Pavia to Bologna, von Eyb followed him. In Bologna, von Eyb met Lamola and joined the little circle that included Pirckheimer and Heller. The fruits of von Eyb's encounter with Italian humanism appear in the Margarita poetica, which Gianni Zippel has characterized as a manual of rhetoric whose model speeches were all fifteenth-century compositions, except for one sermon by Jerome. Among the contemporary speeches, von Eyb, like Schedel, chose to include Lamola's panegyric of Jerome. ${ }^{17}$ So, Italian humanists of the Barzizza and Guarino schools taught eloquence based upon contemporary models, and Jerome afforded a measure of sacral protection for their rhetorical pedagogy. The sermon of Jerome that von Eyb chose to include is an apology for the value of rhetoric for believers. Though Jerome acknowledges in the sermon that one can proclaim the

14 [49], pp. 104, 113-14, 236-38 (Lamola's letter to Pirckheimer from late 1448); and [50], 7, pp. 701-2. The grandson of Hans, Willibald Pirckheimer (1475-1530), had Albrecht Dürer design a bookplate for him with the inscription "Sibi et amicis"; see [34], pp. 97-98.

15 [51], 1, pp. 1-75; and [52], pp. 75-76. Belloni questions whether the Iohannes adolescens whom Lamola mentions in his letter to Pirckheimer was Heller, given that Heller was ca. 34 years old at the time and had earned degrees in arts and in civil and canon law. I concur with scholars who believe that Lamola does refer to Heller. Lamola might be using adolescens in a Roman sense or as a way to tease the older Heller.

16 [53], p. 370; [54], pp. 411-19, 439-58; and [55], pp. 5-7. München, Staatsbibliothek, cod. Clm 504 has at least seven orations by Lamola. On humanist pedagogy at Bologna in the second half of the fifteenth century, see also [56], pp. 209-10, 216-19.

17 [53], pp. 378-79; and [57], 1, pp. 182-83, who notes the presence of the autograph in Eichstätt, Staatsbibliothek, cod. 633. Sottili remarks that, in the Margarita, von Eyb also acknowledged the impact of lectures on rhetoric he attended at the University of Pavia; see [58], p. 131. For von Eyb's thinking on women and whether a man should marry, see [59], pp. 734-49. 
Christian Gospel effectively without any formal rhetorical training, he proposes that, by using rhetorical skills, one will evangelize in a way that deepens the impact of the message and causes it to take lasting root in the hearts of believers.

Thanks to Albrecht von Eyb, Giovanni Lamola, Pierpaolo Vergerio and other humanists, we have acquired a sense of the importance of Jerome as the patron saint of humanist rhetoricians. A remote echo of that Renaissance cult may have led Charles William Dyson Perrins (1864-1958) to invest the profits from his manufacture of Worcestershire sauce in a luxury Quattrocento Jerome codex. The codex illustrates that every manuscript book has its own personal history hinted at by clues left therein. ${ }^{18}$ This particular codex has a collection of Jerome's letters that the scribe Giovanni Grasso di Carpi completed copying in Ferrara on 28 February 1467. No expense was spared: Jerome's letters are written on parchment in an antiqua characterized by its small corpus and long descenders. The first folio has an interlacing white vine border on red, blue, green and gold background. Key elements like the bordering of green leaves along the bottom and right side of that folio are edged in gold ([60], 1, pp. 179-82 and 2, plate 73; [61], 3, pp. 57-61).

In the midst of a wreath of green leaves, the illuminator of the manuscript placed a coat of arms featuring a lion rampant, which leads to a first question: whose coat of arms is it? Sir George Warner suggests two possibilities: the Acciaiuoli family or the family of Grasso himself. If the coat of arms belongs to the Acciaiuoli family-and Warner sees a clear resemblance to the Acciaiuoli arms-then why did Grasso sell the manuscript to someone else two years after he had finished it? Logically, it would go to the Acciaiuoli as commissioners. So Warner feels more inclined to attribute the coat of arms to the Grasso family because their shield also featured a lion rampant. The two-year lag in sale may also be indicative: the Acciaiuoli may have turned down the completed work and it took Grasso a while to sell a book decorated with their coat of arms, or perhaps, after a time, he decided to turn his labor to profit and could only sell a codex with his own family shield to an eager collector like Battista Panetti (ca. 1439-97).

Mystery 2: why did the notary son of a family with a coat of arms choose to earn a living copying luxury manuscripts? We do know that Giovanni Grasso copied other codices: Ovid's Fasti in 1460, Horace and Propertius in 1461, Virgil in 1464, Guarino's translation of Strabo in 1470 and a collection of humanist poetry in the codex Bevilacqua (Est. lat. 1080) ([60]; [61]; [62], p. 128; [1], 1, pp. 383b$84 \mathrm{a}$, and 4, pp. 180b-81a). We also know a good deal about the copying of the Jerome manuscript thanks to Grasso's subscription. He finished his work in the home of Niccolò da Campo, he paid homage to the duke of Ferrara, Borso d'Este (1413-71), he offered an invocation to Jesus, Mary, Saints George and Maurelius (patrons of Ferrara) and Saints Jerome and Peter Martyr (patrons of Giovanni) and he ended with a prayer that his heavenly patrons guide him on the path of good (iter bonum!), defend his soul from the attack of the ancient enemy and his body from a deceitful tongue or a royal assault. ${ }^{19}$ Giovanni Grasso therefore had a personal devotion to Jerome, whose works he

18 [32], p. 3: "The bibliographer's ideal would be to compel each and every volume to tell its own history; the clues by which this goal may in many cases be attained would not displease the mind of the modern reader of mystery-fiction, and the brain of an ideal bibliographer, tracing the pedigree of a manuscript, works not infrequently in the same grooves as the ideal detective of Sir Arthur Conan Doyle."

19 The phrase "deceitful tongue" (lingua dolosa) occurs in Psalm 120:2 (Vulg. Ps. 119:2). 
copied, flattered the d'Este rulers of Ferrara, where he lived, and abused the hospitality of friends, whose study he littered with spilled ink and torn parchment. Mystery 3: what king would care enough about a scribe working in the home of Niccolò da Campo to attack him there? Mitto in silentium.

Evidence establishes that, once Giovanni had finished copying the letters, it took him almost two years to sell the codex. Text on the flyleaf mentions a cashier's note (nota de cassa) from 17 February 1469 recorded in an Argenti bank register, likely bound in red. The evidence indicates that Battista Panetti had three days earlier paid Michele Argenti for the purchase of the Jerome codex copied by Grasso and for a Suetonius codex copied by another scribe. Anton von Euw and Joachim Plotzek suggest the possibility that Grasso used his finished codices to obtain financing from the Argenti bank for his copying business and would then deposit a completed codex with the bank, which handled the sale as payment on the loans ([61], 3, p. 60). Panetti, in turn, was a Carmelite friar and avid book collector, and the codex records the day of his death, 27 March 1497 ([63], pp. 183-228). The codex remained in the possession of the Carmelite friars at the convent of San Paolo in Ferrara where Francesco Antonio Zaccaria (1714-95) saw it in 1757 during his "iter italicum" and mentioned it in print five years later.

In 1810, according to a possessor's note on the first flyleaf, the codex had passed into the hands of Francesco Mainardi in Ferrara. The next notice of the codex is found in the General Catalogue of books offered for sale by Bernard Alexander Christian Quaritch (1818-99) in London in 1868. To maximize the market value of the manuscript, Quaritch made the dubious claim that "[i]t may be remarked that this voluminous and interesting correspondence of St. Jerome is of very unusual occurrence in Manuscript." ${ }^{20}$ The book was auctioned by Sotheby's in 1877 where an unnamed Austro-Hungarian nobleman purchased it. The connoisseur-artist Charles Fairfax Murray (1849-1919) bought the book in 1900, probably for its illumination. Dyson Perrins then dipped into his Worcestershire sauce profits and bought the codex from Fairfax Murray in 1906. Sotheby's auctioned the manuscript a second time in 1959 when Arthur Rau (1898-1972), an English rare book dealer operating from Paris, bought it. The codex ultimately retained its appeal to manufacturers of foodstuffs since the chocolatiers, Peter Ludwig (1925-96), and his wife Irene (1972-2010) purchased the book and kept it for a time in Cologne. In 1983, the J. Paul Getty Museum in Los Angeles purchased at Sotheby's the entire lot of 144 illuminated manuscripts in the Ludwig Collection. In our age of indiscretion, of course, there is also a rumored price for the sale, a price befitting the Getty of forty million dollars. ${ }^{21}$

The final clues worth mentioning are those related to a question that Kristeller posed in his introduction to the fourth volume of his Iter: to what were the persons who wrote or collected the manuscripts committed ([1], 4, p. xxiii)? Among craftsmen who either copied manuscript books or produced portolan charts, there is an admirable group who preferred to hide their identity and let the text or chart speak for itself. They did, at times, supply a clue: their initials. In one subscription, the scribe M. C. actually gave voice to Bruni's translation of Xenophon: “Thus ends Xenophon's book On Tyranny, and M. C. wrote me, whom Leonardo of Arezzo translated from the Greek language into

20 [64], p. 7 (no. 36). See also [32], pp. 158-68.

21 [65], p. 246. The expression "age of indiscretion" was coined by Bettini [66]. 
Latin." 22 The portolan chartmaker, Jacopo Maggiolo (d. ca. 1605), seems an early exponent of "the art of making the best of a difficult situation" (l'arte di arrangiarsi). After a fertile career producing charts from 1551 until 1573, Maggiolo gave no further signs of activity at Genoa until 1602. Out of nowhere, Jacopo reappeared that year and made a portolan chart conserved today in Milan. Corradino Astengo got on the case and noticed signs of scraping by a razor blade on the parchment below the date "1602." Astengo's deduction: Maggiolo may have pulled an old chart off a storage shelf in 1602 and quickly updated it by falsifying the year of its manufacture. If Maggiolo — or a subordinate at his request - did counterfeit the chart, he had a motive. Even though Maggiolo was likely old and infirm in 1602, he proved to the government of Genoa that he could still produce a chart as good as the ones he had made thirty years earlier. And if that was his ruse, it worked. The government continued to pay Maggiolo a salary until 1605 ([68], pp. 83-84).

Numerous members of the Renaissance clergy either wrote works or owned books. For some reason, this detective feels drawn to search for the clues that might indicate to what those clergymen were committed. A priest like Tommaso Baldinotti (1451-1511) in Florence focused on the quality of his handwriting and not the quality of his life. He wrote vernacular and Latin elegies in a clear humanist cursive hand, but he was hardly a moral paragon, engaging in bawdy discussions and amorous liaisons ([1], 2, p. 110a-b; [69], 5, pp. 493-95). A bishop like Pierre de Versailles (1380?1446) seemed focused on using his noble and clerical status to pile up prestigious and remunerative benefices. Pierre accumulated those benefices as apparent rewards for services rendered but did little or nothing to provide pastoral assistance to his various flocks. While at the Council of Basel, Pierre was accused of backing Pope Eugene IV in order to become a cardinal. Eugene did trust Pierre sufficiently to make him part of an embassy to Constantinople from 1437-38, where Pierre gave public speeches and negotiated for a Council under papal patronage to reunite Catholic and Orthodox churches. Having outmaneuvered a parallel delegation from Basel, Pierre accompanied the Greek representatives on their journey to the West. As a proven supporter of papal monarchy and papal ambassador to Charles VII of France, Pierre won appointment to the bishopric of Meaux in 1439. Someone with noble roots in Versailles seems fated for attraction to the most powerful courts of the day. In addition to the discourses in Constantinople, Pierre preached on important occasions at the Council of Basel, including Jerome's feast day. Enea Silvio Piccolomini characterized his preaching as having "more chutzpah than eloquence." On another occasion, Pierre was said to have rushed into the midst of a meeting of the Council and stirred up "many animated altercations," suggesting the unseemly possibility of fisticuffs between assembled Church dignitaries. ${ }^{23}$ One cannot help but wonder if the choice to have Pierre preach on Jerome was subconscious typecasting.

Other clergymen balance the picture. Bishop Bernhard von Krayburg (1412-77) gathered a large and important library at his castle in Chiemsee (Salzburg). He was instrumental, for example, as a

22 Udine, Biblioteca Arcivescovile, cod. 49, fol. 49, cited by [67], p. 120: "Explicit liber Xenophontis de tyrannide et M. C. me scripsit quem Leonardus Aretinus ex greco sermone in latinum convertit."

23 [70], pp. 208-66, esp. p. 230, where Coville quotes Piccolomini's letter of 20 May 1437, “... plus animi habens quam eloquentiae." [70], p. 265, sees Pierre's commitment similarly: "Il dut être plutôt ambitieux: il eut de nombreux benefices...." The "Sermo" for Jerome that Pierre de Versailles delivered at Basel in 1435 was conserved in cod. 118, fols. 330v-37v, of the Staats- und Universitätsbibliothek in Kaliningrad (Königsberg) but is now lost; see [1], 5, p. $167 \mathrm{a}-\mathrm{b}$. 
conduit for Bruni's letters to Germany, and he also owned codices with the marrow of Petrarch's humanist ideas. From that intersection between humanist and religious cultures, von Krayburg developed a personal affection for letters, a profound sense of spirituality and a firm commitment to reform the lives of his clergy ([71], p. 95; [38], 1, p. xxxiii). The efforts to study classical languages, collect books and reform the clergy that bishops like Bernard von Krayburg and Johann Roth made helped to reshape the ideal of episcopal sanctity in German-speaking lands ([55], p. 17; [47], pp. 39798; [72], pp. 43-48). Battista Panetti, the Carmelite professor of theology who owned the Jerome codex that Dyson Perrins later acquired, collected humanist works, copied ancient inscriptions and probably learned Greek. While working in the scriptorium of his convent of San Paolo in Ferrara, Panetti developed his respect for books and his desire to protect them as valuable witnesses to the past. In building his collection, the Carmelite would gather individual fascicles, organize them in chronological order, bind them together, add a Latin epigram on the flyleaf and supply at least a partial table of contents for the new composite volume. Panetti's embrace of humanism led him to assume a public commitment as well, functioning as a secret counselor to Duke Ercole I (1431-1505), entering friendships with leading humanists like the Duke's orator, Ludovico Carbone (1435-82), and even giving an occasional speech himself. The tolerance of his book collecting is mirrored at least once in the tolerance of his public advocacy. When the local Dominican inquisitor, Paolo da Bologna, condemned a scholar to burning at the stake for a mistaken interpretation of Scotus, Panetti decried the unjust verdict ([73], p. 310; [62], pp. 183-92).

There are also practitioners of classical philology and humanist rhetoric who later took a serious interest in Scriptural study. Agostino Dati (1421-78) accepted an appointment by his bishop to lecture on the Scriptures in Siena, and Bartolomeo Fonzio (Della Fonte, 1446-1513) came out of retirement in part to do the same at the University of Florence. There may be manuscript books somewhere in the Iter that offer clues as to what those two learned humanists said in their lectures on sacred letters ([75]; [35], pp. 60-68; [76], pp. 810-13). But the choices speak for themselves, as do Panetti's tolerant choices in collecting books and decrying injustice. Tolerance, moreover, seems an appropriate note on which to end a discussion of Renaissance manuscripts as private property or common wealth. In the introduction to a translation of Vitruvius, Frank Granger observed that Vipsanius Agrippa (ca. 63-12 BCE) by his geography and Asinius Pollio (76 BCE-4 CE) by his library helped expand the horizons of literate Romans of the age of Augustus. Granger's characterization of the contribution of Asinius Pollio seems germane to this paper, for Granger follows Pliny and others in arguing that, because Asinius Pollio assembled the literature and science of the time in the first public library at Rome, he "made human genius a common possession (res publica)" ([76], p. xvii, citing Pliny N.H. 35.2.10; [77], pp. 244-45). Such an endeavor is shot through with tolerance, in the works collected and in the accessibility granted.

Even a cursory journey through the vast resources of Kristeller's six volumes sensitizes one to the relevance of the tension between books as private property and books as common wealth. Abuse of borrowing privileges from a public library goes on. College professors, myself included, may scruple at times about our ability to withdraw a book for an entire semester or academic year, especially when we compare the amount of time we consult the book to the amount of time it sits idle on our bookshelf where it is unavailable to others. A public ethos might lead us to keep the book out of the library for the minimum amount of time. European libraries have long worked to develop other creditable 
solutions, from chaining their books to a reading stand in the Renaissance to creating in our own day authentic research libraries where books never leave the premises. Individuals still exploit their social prestige to gain special access to valuable books, and individuals still steal valuable books and sell them on open and black markets. Manuscript books are a marketable commodity, and the marketing of Renaissance manuscripts runs the capitalist gamut from crass speculation to responsible entrepreneurship. At its worst, it represents a violation of the public trust twice over: the theft of a book in the first place and the sale of the stolen book in the second. Moreover, in an effort to acquire resources of use to the public, institutions and libraries have had a difficult time resisting the temptation to deal with disreputable sellers.

There are various ways to measure the value of a manuscript. As a container for words and the thought that they express, books are material objects put together from bundles of parchment or paper and bound together inside a variety of covers. Some collectors have bought manuscripts solely for the quality of their material production. Such manuscripts become luxury items akin to a Rolex watch. One can tell the time with a far less expensive Timex watch, and, to the delight of John Cameron Swayze (1906-95), the Timex may well be "still ticking." Most surviving manuscripts from the Renaissance, however, originated in the study of the humanities, a curriculum that revolutionized adolescent education and held sway for centuries in the Western world. Their value was not calculated in terms of cost of production and profit from resale, but in terms of assembly of contents and assistance to an education that, thanks to that compendium of texts, should last a lifetime. A student who owned such a manuscript book could always consult its particular texts whenever professional or personal needs so dictated. When one student shared his compendium with another, the educational fruits were multiplied and humanist culture more widely diffused. Magnanimous scholars did not hesitate to label a manuscript the common property of themselves and their friends. Treating a manuscript as a common wealth fostered a sense of human genius as a common possession and a concomitant spirit of tolerance. A good adage, no matter what its source, was applicable to the experience of all human beings, and genuine human insight, even by pagan authors, had appropriate application to the good and holy living of Christians. Committed bishops who had learned the humanities promoted moral reform.

Given such interrelationships, it was vital that a scribe accurately copy texts into the manuscript. Alcuin of York (d. 804) composed a poem that he affixed as an inscription (titulus) in a monastic scriptorium to remind copyists of the importance of what they were doing and the accuracy with which they did it. For the Carolingian monk, copying books supplied a more valuable service than pruning vines, for, while the latter assisted only the physical appetite, the former served the human spirit. ${ }^{24}$ Nonetheless, and ironically, some of the most valuable Renaissance manuscripts from a material perspective are among the least valuable from a textual perspective. Perhaps more ironically, sloppy copying did not always reduce the value of the manuscript in the eyes of prestigious owners, leading one to wonder if they ever read the texts in the book. Ultimately, the history of each individual Renaissance manuscript illustrates the tension between private property and common wealth, for the book regularly moved from private to public ownership and back again. Battista Panetti made the

24 Alcuin, Carmen 94, in [78], p. 320. See also [79], p. 33; [80], pp. 35-36; and [81], pp. 34-35. I thank T. C. Price Zimmermann for suggesting Alcuin to me. 
Jerome text copied by Giovanni Grasso available to the Carmelite friars of his convent in Ferrara and, presumably, to learned visitors to that convent. After all, friars take a vow to hold all property in common. Charles William Dyson Perrins limited the circulation of the codex after he had purchased it to enhance his collection of illuminated manuscripts. The Getty Research Center, thanks to its vast resources, was once again able to make the codex available for wider consultation. Throughout its journey, the manuscript remained a container for the words and thought of human intelligence. For that reason, we too provide a service to the human spirit when we join Pliny in lionizing Asinius Pollio for establishing a public library in Rome. We thereby acknowledge human genius as our common wealth.

\section{References}

1. Paul Oskar Kristeller. Iter Italicum: A Finding List of Uncatalogued or Incompletely Catalogued Humanistic Manuscripts of the Renaissance in Italian and Other Libraries. Leiden: Brill, 196392, 6 vols.

2. Carlo Ginzburg. "Clues: Roots of an Evidential Paradigm." In Clues, Myths and the Historical Method, translated by John and Anne Tedeschi. Baltimore, Mar.: Johns Hopkins Univ. Press, 1989, 96-125.

3. Saturnino Loggi. I codici della Libreria di S. Giacomo della Marca nel Museo Civico di Monteprandone: Catalogo. Introduction by Mauro Mai. Monteprandone: Centro Regionale per i Beni Culturali, 2000.

4. Emmanuele Antonio Cicogna. Delle inscrizioni veneziane. Venezia: presso la Tipografia Andreola, 1824-61, 6 vols.

5. Carlo Castellani. "Il prestito dei codici manoscritti della biblioteca di San Marco in Venezia ne' suoi primi tempi e le conseguenti perdite de' codici stessi: Ricerche e notizie." Atti del Reale Istituto veneto di scienze, lettere ed arti 55, no. 1 (1896-97): 311-77.

6. Lotte Labowsky. Bessarion's Library and the Bibliotheca Marciana: Six Early Inventories. Roma: Edizioni di Storia e Letteratura, 1979.

7. Marino Zorzi. La Libreria di San Marco: Libri, lettori, società nella Venezia dei Dogi. Milano: Arnoldo Mondadori, 1987.

8. Daria Perocco. "Uno storico mancato, un viaggiatore involontario: Il caso di Andrea Navagero." In Forma e parola: Studi in memoria di Fredi Chiappelli, edited by Dennis J. Dutschke, Pier Massimo Forni, Filippo Grazzini, Benjamin R. Lawton and Laura Sanguineti White. Roma: Bulzoni, 1992, 327-39.

9. Thomas William Allen. Notes on Greek Manuscripts in Italian Libraries. London: David Nutt, 1890.

10. José M. March. "Documentos insignes que pertenecieron al Cardenal Zelada tocantes a la Compañiá de Jesús.” Archivum Historicum Societatis Iesu 18 (1949): 118-25.

11. Giovanni Mercati. Note per la storia di alcune biblioteche romane nei secoli XVI-XIX. Città del Vaticano: Biblioteca Apostolica Vaticana, 1952.

12. Jeanne Bignami-Odier. La Bibliothèque Vaticane de Sixte IV à Pie XI: recherches sur l'hístoire des collections de manuscrits. Città del Vaticano: Biblioteca Apostolica Vaticana, 1973. 
13. Catalogue of Additions to the Manuscripts in the British Museum in the Years 1848-1853. London: Trustees of the British Museum, 1868.

14. Aubery Diller. "The Vatopedi Manuscript of Ptolemy and Strabo." American Journal of Philology 58, no. 2 (1937): 174-84. Repr. in Studies in Greek Manuscript Tradition. Amsterdam: Adolf M. Hakkert, 1983, 7-17.

15. - The Tradition of the Minor Greek Geographers. American Philological Association, 14. Oxford: Blackwell, and Lancaster, Pa.: Lancaster Press, 1952.

16. - The Textual Tradition of Strabo's Geography. Amsterdam: Adolf M. Hakkert, 1975.

17. Giuseppe Fumagalli. Guglielmo Libri, edited by Berta Maracchi Biagiarelli. Firenze: Leo S. Olschki, 1963.

18. A. N. L. Munby. "The Earl and the Thief: Lord Ashburnham and Count Libri." Harvard Library Bulletin 17 (1969): 5-21.

19. _ . "The Triumph of Delisle: A Sequel to "The Earl and the Thief," Harvard Library Bulletin 17 (1969): 279-90.

20. P. Alessandra Maccioni Ruju, and Marco Mostert. The Life and Times of Guglielmo Libri (18021869) Scientist, Patriot, Scholar, Journalist and Thief: A Nineteenth-Century Story. Hilversum: Verloren, 1995.

21. Pietro Zorzanello. Catalogo dei codici latini della Biblioteca Nazionale Marciana di Venezia non compresi nel catalogo di G. Valentinelli. Trezzano: Etimar, 1980-85.

22. René Hoven, and Laurent Grailet. Lexique de la prose latine de la Renaissance. Leiden and Boston: Brill, 2006.

23. Liliana Monti Sabia. "Altri codici della Naumachia Regia di Ciriaco d'Ancona." In Ciriaco d'Ancona e la cultura antiquaria dell'Umanesimo (Atti del Convegno Internazionale di Studio, Ancona, 6-9 febbraio 1992), edited by Gianfranco Paci and Sergio Sconocchia. Reggio Emilia: Edizioni Diabasis, 1998, 235-51.

24. — ed. Kyriaci Anconitani Naumachia Regia. Pisa and Roma: Istituti Editoriali e Poligrafici Internazionali, 2000.

25. Dennis Dutschke. Census of Petrarch Manuscripts in the United States. Padova: Antenore, 1986.

26. James Hankins. "Bruni Manuscripts in North America: A Handlist." In Per il censimento dei codici dell'Epistolario di Leonardo Bruni (Seminario internazionale di studi, Firenze, 30 ottobre 1987), edited by Lucia Gualdo Rosa and Paolo Viti. Roma: Istituto Storico Italiano per il Medio Evo, 1991, 55-90.

27. Ursula Jaitner-Hahner. "Per la fortuna del 'Codice Bollea." In Per il censimento dei codici dell'Epistolario di Leonardo Bruni (Seminario internazionale di studi, Firenze, 30 ottobre 1987), edited by Lucia Gualdo Rosa and Paolo. Roma: Istituto Storico Italiano per il Medio Evo, 1991, 99-111.

28. Griggio, Claudio, ed. Francesco Barbaro Epistolario. Firenze: Leo S. Olschki, 1991, vol. 1.

29. James Hankins. Repertorium Brunianum: A Critical Guide to the Writings of Leonardo Bruni. Roma: Istituto Storico Italiano per il Medio Evo, 1997, vol. 1.

30. Eduardo Melfi. "Curti, Lancino." Dizionario biografico degli Italiani. Roma: Istituto della Enciclopedia Italiana, 1960, vol. 31, 487-88. 
31. Stefano Meschini. Uno storico umanista alla corte sforzesca: Biografia di Bernardino Corio. Milano: Vita e Pensiero, 1995.

32. Seymour De Ricci. English Collectors of Books and Manuscripts (1530-1930) and Their Marks of Ownership. New York: Burt Franklin, 1969.

33. Alan Bell. "Phillipps, Thomas." In Oxford Dictionary of National Biography, edited by H. C. G. Matthew and Brian Howard Harrison. Oxford and New York: Oxford Univ. Press, 2004, vol. 44, 91-94

34. G. D. Hobson. "“Et amicorum.”" The Library, 5th ser., 4, no. 2 (1949): 87-99.

35. Stefano Caroti, and Stefano Zamponi. Lo scrittoio di Bartolomeo Fonzio umanista fiorentino. Milano: Edizioni Il Polifilo, 1974.

36. Marianna D. Birnbaum. "Janus Pannonius, Bartolomeo Melzi and the Sforzas." Renaissance Quarterly 30 (1977): 1-7.

37. Simona Brambilla. "Il codice Ambr. H 52 sussidio e l'Orthographia di Matteo Ronto." In Nuove ricerche su codici in scrittura latina dell'Ambrosiana: Atti del Convegno, Milano, 6-7 ottobre 2005, edited by Mirella Ferrari and Marco Navoni. Milano: Vita e Pensiero, 2007, 229-52.

38. Lucia Gualdo Rosa, et al. Censimento dei codici dell'Epistolario di Leonardo Bruni. Roma: Istituto Storico Italiano per il Medio Evo, 1993, vol. 1. Roma: Istituto Storico Italiano per il Medio Evo, 2004, vol. 2.

39. Arnaldo Segarizzi. "Antonio Carabello umanista bergamasco del secolo XV." Archivio storico lombardo 30, fasc. 40 (1903): 470-83.

40. Frank Rutger Hausmann. "Carabello, Antonio." Dizionario biografico degli Italiani. Roma: Istituto della Enciclopedia Italiana, 1960-, vol. 19, 300-1.

41. Kathy Eden. Friends Hold All Things in Common: Tradition, Intellectual Property and the "Adages" of Erasmus. New Haven and London: Yale Univ. Press, 2001.

42. Erasmus Roterodamus. Opera omnia recognita et adnotatione critica instructa notisque illustrata, edited by M. L. van Poll-van de Lisdonck, M. Mann Phillips and Chr. Robinson. Amsterdam, London, New York and Tokyo: North-Holland, 1993, part 2, vol. 1.

43. Desiderius Erasmus. The Collected Works of Erasmus, translated by Margaret Mann Phillips, and annotated by R. A. B. Mynors. Toronto, Buffalo and London: Univ. of Toronto Press, 1982, vol. 31.

44. Juan Guillén Torralba. Hernando Colón: Humanismo y bibliofilia. Sevilla: Fundación José Manuel Lara, 2004.

45. Edward Muir. The Leopold von Ranke Manuscript Collection of Syracuse University: The Complete Catalogue. Syracuse, N. Y.: Syracuse Univ. Press, 1983.

46. Agostino Sottili. "Ehemalige Studenten italienischer Renaissance-Universitäten: Ihre Karrieren und ihre soziale Rolle." In Humanismus und Universitätsbesuch: Die Wirkung italienischer Universitäten auf die "Studia Humanitatis" nördlich der Alpen. Leiden and Boston: Brill, 2006, 326-67.

47. _ "The Humanist Education of Johannes Roth, Prince-Bishop of Breslau." In Humanismus und Universitätsbesuch: Die Wirkung italienischer Universitäten auf die "Studia Humanitatis" nördlich der Alpen. Leiden and Boston: Brill, 2006, 396-412. 
48. —. "Der Bericht des Johannes Roth über die Kaiserkrönung von Friedrich III." In Humanismus und Universitätsbesuch: Die Wirkung italienischer Universitäten auf die "Studia Humanitatis" nördlich der Alpen. Leiden and Boston: Brill, 2006, 413-61.

49. Arnold Reimann. Die älteren Pirckheimer: Geschichte eines Nürnberger Patriziergeschlechtes im Zeitalter des Frühhumanismus (bis 1501). Leipzig: Koehler \& Amelang, 1944.

50. Franz Josef Worstbrock. "Pirckheimer, Hans." In Die deutsche Literatur des Mittelalters: Verfasserlexikon, 2nd ed. Berlin and New York: Walter de Gruyter, 1978-99, vol. 7, 701-3.

51. Ludwig Bertalot. "Eine humanistische Anthologie: Die Handschrift $4^{\circ} 768$ der Universitätsbibliothek München." In Studien zum italienischen und deutschen Humanismus, edited by Paul Oskar Kristeller. Roma: Edizioni di Storia e Letteratura, 1975, vol. 1, 1-82.

52. Annalisa Belloni. "Iohannes Heller e i suoi libri di testo: Uno studente tedesco a Padova nel Quattrocento tra insegnamento giuridico ufficiale e natio Theutonica." Quaderni per la storia dell'Università di Padova 20 (1987): 51-99.

53. Gianni Zippel. "Gli inizi dell'Umanesimo tedesco e l'Umanesimo italiano nel XV secolo." Bullettino dell'Istituto Storico Italiano per il Medio Evo e Archivio Muratoriano 75 (1963): 345-89.

54. Agostino Sottili. "I codici del Petrarca nella Germania Occidentale." Italia medioevale $e$ unmanistica 10 (1967): 411-91.

55. - Studenti tedeschi e umanesimo italiano nell'Università di Padova durante il Quattrocento. Padova: Antenore, 1971, vol. 1.

56. Paul F. Grendler. The Universities of the Italian Renaissance. Baltimore and London: Johns Hopkins Univ. Press, 2002.

57. Gerhard Klecha. "Albrecht von Eyb." In Die deutsche Literatur des Mittelalters: Verfasserlexikon. Berlin and New York: Walter de Gruyter, 1978-99, 2nd ed., vol. 1, 180-86.

58. Agostino Sottili. "Der Rhetorikunterricht an der Universität Pavia in der zweiten Hälfte des 15. Jahrhunderts." In Humanismus und Universitätsbesuch: Die Wirkung italienischer Universitäten auf die "Studia Humanitatis" nördlich der Alpen. Leiden and Boston: Brill, 2006, 119-42.

59. Prudence Allen, R.S.M. The Concept of Woman. Grand Rapids, Mich., and Cambridge: Wm. B. Eerdmans, 2002, vol. 2.

60. Sir George Warner. Descriptive Catalogue of Illuminated Manuscripts in the Library of C. W. Dyson Perrins. Oxford: Oxford Univ. Press, 1920.

61. Anton von Euw, and Joachim M. Plotzek. Die Handschriften der Sammlung Ludwig. Köln: Schnütgen-Museum, 1979-85.

62. Giulio Bertoni. Guarino da Verona fra letterati e cortigiani a Ferrara (1429-1460). Genève: Leo S. Olschki, 1921.

63. Claudia Andreasi. "La biblioteca di frate Giovanni Battista Panetti Carmelitano." Medioevo $e$ Rinascimento 14 (2000): 183-231.

64. A General Catalogue of Books Arranged in Classes, Offered for Sale by Bernard Quaritch. London: 15 Piccadilly, 1868.

65. Donald C. Dickinson. Dictionary of American Antiquarian Bookdealers. Westport, Conn., and London: Greenwood Press, 1998.

66. Maurizio Bettini. I classici nell'età dell'indiscrezione. Torino: Einaudi, 1995.

67. Cesare Scalon. La biblioteca arcivescovile di Udine. Padova: Antenore, 1979. 
68. Corrado Astengo. La cartografia nautica mediterranea dei secoli XVI e XVII. Genova: Erga edizioni, 2000.

69. Armando Petrucci. "Baldinotti, Tommaso." In Dizionario biografico degli Italiani. Roma: Istituto della Enciclopedia Italiana, 1960-, vol. 5, 493-95.

70. Alfred Coville. "Pierre de Versailles (1380?-1446)." Bibliothèque d l'École des Chartres 93 (1932): 208-66.

71. Frank Rutger Hausman. "Manoscritti di Leonardo Bruni nella Repubblica Democratica Tedesca e nella Repubblica Federale Tedesca meridionale." In Per il censimento dei codici dell'Epistolario di Leonardo Bruni (Seminario internazionale di studi, Firenze, 30 ottobre 1987), edited by Lucia Gualdo Rosa and Paolo Viti. Roma: Istituto Storico Italiano per il Medio Evo, 1991, 91-97.

72. David J. Collins. Reforming Saints: Saints' Lives and Their Authors in Germany 1470-1530. Oxford, New York et al.: Oxford Univ. Press, 2008.

73. Alessandra Chiappini. "Fermenti umanistici e stampa in una biblioteca ferrarese del secolo XV." La Bibliofilia 85 (1983): 299-320.

74. Paolo Viti. "Dati, Agostino." Dizionario biografico degli Italiani. Roma: Istituto della Enciclopedia Italiana, 1960, vol. 33, 15-21.

75. Raffaella Zaccaria. "Della Fonte (Fonzio), Bartolomeo." In Dizionario biografico degli Italiani. Roma: Istituto della Enciclopedia Italiana, 1960, vol. 36, 808-14.

76. Vitruvius. De architectura. Frank Granger, trans. Cambridge, Mass.: Harvard Univ. Press, and London: William Heinemann, 1956, vol. 2.

77. Polydore Vergil. On Discovery. Edited by Brian P. Copenhaver. Massachusetts and London: Harvard Univ. Press, 2002.

78. Ernst Dümmler, ed. Poetae Latini aevi Carolini. Monumenta Germaniae historica, Poetae, 1. Berlin: Weidmann, 1881.

79. David Ganz. "The Preconditions for Caroline Minuscule." Viator 18 (1987): 23-44.

80. M. B. Parkes. Pause and Effect: An Introduction to the History of Punctuation in the West. Berkeley and Los Angeles: Univ. of California Press, 1993.

81. Anna A. Grotans. Reading in Medieval St. Gall. Cambridge, New York et al:: Cambridge Univ. Press, 2006.

(C) 2012 by the author; licensee MDPI, Basel, Switzerland. This article is an open access article distributed under the terms and conditions of the Creative Commons Attribution license (http://creativecommons.org/licenses/by/3.0/). 